\title{
A Circulating Inhibitor of Fluid-Phase Amplification C3 Convertase Formation in Systemic Lupus Erythematosus
}

F. Bryson Waldo, Judith Forristal, Linda Beischel, and Clark D. West Children's Hospital Research Foundation and the Department of Pediatrics, University of Cincinnati College of Medicine, Cincinnati, Ohio 45229

\begin{abstract}
C3 nephritic factor (C3NeF) was used to assess the formation of the fluid-phase amplification convertase, $\mathbf{C} 3 \mathbf{b}, \mathbf{B b}$, in 37 serum specimens from 24 patients with systemic lupus erythematosus (SLE). C3b,Bb formation was measured by the concentration of $\mathrm{Ba}$, released when $\mathrm{C} 3 \mathrm{~b}, \mathrm{~B}$ is activated. Incubation of normal human serum (NHS) with $\mathrm{C} 3 \mathrm{NeF}$ accelerates $\mathrm{C} 3 \mathrm{~b}$ amplification loop turnover with the formation of large quantities of $\mathrm{C} 3 \mathrm{~b}, \mathrm{Bb}$. In contrast, sera from 22 of 24 patients with SLE formed little or no convertase when incubated with $\mathrm{C} 3 \mathrm{NeF}$. $\mathrm{C} 3$ conversion to $\mathrm{C} 3 \mathrm{~b}$ was commensurately reduced. The inhibition could not be attributed to depressed serum concentrations of C3, factor B, or classical pathway components. Inhibitor present in excess could be demonstrated in 23 of 34 specimens of SLE serum by mixing experiments. The spontaneous convertase formation that occurs when a portion of the serum $H$ is inactivated with $\mathbf{F}\left(\mathbf{a b}^{\prime}\right)_{2}$ anti-H was also shown to be inhibited in SLE serum. The inhibition was found, however, to be $H$ dependent in that convertase formation was normal in SLE serum depleted of $\mathrm{H}$. It is concluded that the C3b in most SLE sera is unusually susceptible to inactivation by $H$, but a functional abnormality was not demonstrable in either $\mathrm{C} 3$ or $H$ isolated from SLE serum. The inhibition could be simulated in NHS by addition of heparin, $100 \mu \mathrm{g} / \mathrm{ml}$. In vivo, inhibition of convertase formation could interfere with the solubilization and disposal of immune complexes by reducing the deposition of $\mathrm{C} 3 \mathrm{~b}$ on the immune complex lattice.
\end{abstract}

\section{Introduction}

From data accumulated in recent years, investigators have inferred that certain defects in the serum complement system would predispose to immune complex disease $(1,2)$. The removal of immune complexes from the circulation and their disposal by the mononuclear phagocyte system is dependent on the deposition of C3b on the complex (3). Specifically, the deposition of $\mathrm{C} 3 \mathrm{~b}$ results in a reduction in complex size (4), in an increase in solubility (4), and in binding of the complex to phagocytes, which leads to their ingestion $(5,6)$. Deposition of $\mathrm{C} 3 \mathrm{~b}$ is initiated by immune complex activation of the

This paper was presented at the 16th annual meeting of the American Society of Nephrology, 1983.

Address reprint requests to Dr. West, Children's Hospital Medical Center.

Received for publication 5 March 1984 and in revised form 11 January 1985.

J. Clin. Invest.

(c) The American Society for Clinical Investigation, Inc. 0021-9738/85/06/1786/10 \$1.00

Volume 75, June 1985, 1786-1795 classical pathway and the formation of the classical convertase, $\mathrm{C} 4 \mathrm{~b}, 2 \mathrm{a}$. The deposited $\mathrm{C} 3 \mathrm{~b}$, with factors $\mathrm{B}, \mathrm{D}$, and properdin, forms the more vigorous amplification $\mathrm{C} 3$ convertase, $\mathrm{C} 3 \mathrm{~b}, \mathrm{Bb}, \mathrm{P}$ (7), which results in further $\mathrm{C} 3 \mathrm{~b}$ deposition. Thus, the proteins essential for solubilization are $\mathrm{C} 3$ and factors $\mathrm{B}, \mathrm{D}$, and $\mathrm{P}$. In addition, factors $\mathrm{H}$ and $\mathrm{I}$ are necessary to regulate the reaction leading to $\mathrm{C} 3 \mathrm{~b}, \mathrm{Bb}$ formation (8). In vivo, the erythrocyte $\mathrm{C} 3 \mathrm{~b}$ receptor (CR-1) may substitute for factor $H$ (9). In whole serum, solubilization can occur in the absence of the classical pathway, but with this pathway intact it is more rapid and complete (2).

A functional defect in the serum complement system that inhibits $\mathrm{C} 3 \mathrm{~b}$ deposition could therefore result in disease by compromising the processing and clearance of potentially pathogenic complexes. It is well known that specific inherited defects in the complement system can be associated with immune complex disease (10), but in most patients such defects have not been found. Immune complex disease may be accompanied by an acquired hypocomplementemia, but it is often not sufficiently severe to affect immune complex processing.

This report presents evidence for a circulating inhibitor of fluid-phase amplification convertase formation in the sera of patients with systemic lupus erythematosus (SLE). ${ }^{1}$ This inhibition has been demonstrated by using the $\mathrm{C} 3$ nephritic factor (C3NeF) for functional assessment of the $\mathrm{C} 3 \mathrm{~b}$ amplification loop. The response of the loop to $\mathrm{C} 3 \mathrm{NeF}$ has been quantitated in two ways. First, the fragment of factor $\mathrm{B}$, designated $\mathrm{Ba}$, formed when factor $B$ is activated $(11,12)$, has been measured as an index of amplification convertase $(\mathrm{C} 3 \mathrm{~b}, \mathrm{Bb})$ formation. Second, the loss of the $\mathrm{B}$ antigen of $\mathrm{C} 3$ has been used as a measure of $\mathrm{C} 3$ conversion $(13,14)$. Both convertase formation and $\mathrm{C} 3$ conversion in response to $\mathrm{C} 3 \mathrm{NeF}$ were inhibited in the sera of patients with SLE. In addition, inactivation of $\mathbf{H}$ by adding to serum an $\mathrm{F}\left(\mathrm{ab}^{\prime}\right)_{2}$ fragment of anti $\mathrm{H}$ has been used to assess spontaneous fluid-phase convertase formation. Again, amplification loop turnover was inhibited in the sera of patients with SLE relative to that in normal human serum (NHS).

\section{Methods}

Patient data. The studies were done on sera from 24 patients with SLE, from 41 healthy hospital personnel (NHS), and on a pooled NHS (PNHS) from 12 donors. Blood was collected by venipuncture and allowed to clot in glass tubes for $30 \mathrm{~min}$ at room temperature. The serum was separated and either used fresh or stored at $-70^{\circ} \mathrm{C}$. The patients with SLE met the American Rheumatology Association criteria

1. Abbreviations used in this paper: $\mathrm{C} 3 \mathrm{NeF}, \mathrm{C} 3$ nephritic factor; CRP, C-reactive protein; NHS, normal human serum; PEG, polyethylene glycol; PNHS, pooled NHS; RID, radial immunodiffusion; SDSPAGE, SDS polyacrylamide gel electrophoresis; SLE, systemic lupus erythematosus. 
for the diagnosis. All except one were female and all were under the age of 21 yr. Extrarenal SLE was considered to be present in 5 of the 24 patients. They had normal urinalyses and serum creatinine concentrations $\leq 1.1 \mathrm{mg} / \mathrm{dl}$. A patient with renal SLE was considered to be in remission when clinical evidence of disease activity such as rash, arthritis, and neutropenia had disappeared and the serum C3 level, if initially low, had come into the normal range. During a clinical remission, the urinalysis was usually still abnormal but was improved compared with that during periods of active disease.

Measurement of serum complement components. The complement proteins, C3, and factors $\mathrm{H}, \mathrm{I}$, and $\mathrm{B}$, were measured by radial immunodiffusion (RID). For measurement of serum C3 levels, monospecific antiserum to the A determinant of $C 3$ was used (13). The methods for quantitation for the other proteins have been described previously $(15,16)$. All antisera were rendered monospecific by absorption and subjected to octanoic acid precipitation (17) to obtain a preparation enriched in IgG.

Protein isolation. C3 was isolated from pooled normal plasma by the method of Hammer et al. (18) with the addition of a precipitation step using 12\% polyethylene glycol (PEG) 4,000 (Sigma Chemical Co. St. Louis, MO) before chromatography on DEAE Sephacel (Pharmacia Fine Chemicals, Piscataway, NJ). Additional PEG was added to the $12 \%$ supernatant to a final concentration of $45 \%$. The resulting precipitate was redissolved and used as a source for the purification of factor B. The method of Lambris et al. (19) was used with the omission of $\mathrm{C} 3 \mathrm{~b}$ agarose chromatography and the addition of immunoabsorption on a column of anti-C1 inhibitor conjugated to Sepharose 4B. H was isolated from a pool of enriched fractions after DEAE Sephacel chromatography. Contaminants were removed by passage over DNA cellulose (Sigma Chemical Co.) in $10 \mathrm{mM}$ sodium phosphate, $\mathrm{pH} 6.8$, $50 \mathrm{mM}$ sodium chloride, $5 \mathrm{mM}$ EDTA, and elution by a gradient to $0.4 \mathrm{M}$ sodium chloride (20). $\mathrm{C} 3$ and $\mathrm{H}$ were also isolated from a pool of sera drawn on several dates from a patient with SLE who consistently demonstrated excess inhibitor. The starting volume was $8 \mathrm{ml}$ and the same procedure was used as for the proteins from normal plasma.

Functionally pure I was obtained by passage of EDTA treated normal serum over a column of Sepharose 4B to which goat anti-I had been conjugated. Adsorbed material was eluted with $3.5 \mathrm{M} \mathrm{NaSCN}$ and dialyzed into phosphate-buffered saline (PBS). All purified components were homogeneous by polyacrylamide gel electrophoresis in the presence of SDS (SDS-PAGE) and produced bands of appropriate molecular weights. Purified components were dialyzed against PBS before use.

IgG was separated from the serum of one patient and from normal serum by ion exchange chromatography on DEAE Sephacel. The concentration of the IgG preparation was adjusted to that in the original serum and it was dialyzed against veronal-buffered saline with physiologic concentrations of $\mathrm{Ca}++$ and $\mathbf{M g}++$.

Measurement of C3 conversion and amplification convertase formation. C3 conversion was assessed, as previously described (14), by the loss of the B antigen of C3, as measured by RID. The B antigen concentration was expressed in arbitrary units based on its concentration in a reference serum containing $0.04 \mathrm{M}$ EDTA.

Measurement of the Ba fragment of factor $\mathrm{B}$, used as a measure of amplification convertase formation, was by RID and employed two antibodies incorporated in 2\% agarose (Kallestad Laboratories, Inc., Chaska, MN) containing 3\% PEG (3,350 mol wt) (Sigma Chemical Co.). The agarose also contained glycine buffer, $\mathrm{pH} 7.5$, and $0.04 \mathrm{M}$ EDTA. The antibodies were made by immunizing goats with either purified factor B (21) or the Ba fragment of factor B, each incorporated in complete Freund's adjuvant. One antibody in the agarose was directed against determinants common to native factor $\mathbf{B}$ and the $\mathbf{B b}$ fragment $(11,12,22)$. The concentration of this antibody was six times that which would produce measurable precipitin rings for factor B in normal serum. The other antibody was directed against determinants common to native factor $\mathrm{B}$ and the $\mathrm{Ba}$ fragment $(11,12,22)$, and its concentration was such that a large but easily measurable precipitin ring was produced by a specimen of NHS in which all the factor B had been converted to $\mathrm{Ba}$. A totally converted serum was prepared by adding EDTA to a specimen of NHS of known factor B concentration and depleting it of I by immune absorption. The addition of $\mathrm{MgCl}_{2}$ to produce a slight excess of $\mathrm{Mg}++$ converted all the factor $\mathrm{B}$ to $\mathrm{Bb}$ and $\mathrm{Ba}$. The differences between the areas of the outer and inner rings made by this standard and its dilutions were graphed vs. their $\mathrm{Ba}$ concentrations, expressed in milligrams of activated factor B/dl. The standard curve thus obtained was linear. For each experimental specimen, the area of the outer ring minus the area of the dense inner ring was calculated and used to obtain the serum concentration of $\mathrm{Ba}$ from the standard curve. The accuracy of the method depended on native factor $\mathrm{B}$ binding all the anti $\mathrm{Ba}$ in the agarose within the small inner ring. To the extent this did not occur, as in specimens containing large amounts of activated factor $\mathrm{B}, \mathrm{Ba}$ generation would be slightly underestimated.

Activation of serum by C3NeF. Partially purified $\mathrm{C} 3 \mathrm{NeF}$ was prepared from plasma from a patient with membranoproliferative glomerulonephritis type II, kindly provided by Dr. Robert J. Wyatt, University of Tennessee, Memphis, TN. The plasma, obtained by plasmapheresis, was precipitated with octanoic acid (17) and the supernatant, which contained the IgG, was dialyzed against PBS. To measure the ability of large numbers of sera to produce $\mathrm{Ba}, 10 \mu \mathrm{l}$ of the $\mathrm{C} 3 \mathrm{NeF}$ preparation were added to $50 \mu \mathrm{l}$ of each test serum in glass test tubes immersed in an ice bath. The contents of the tubes were then mixed and aliquots removed for measurement of $\mathrm{Ba}$ and the $\mathrm{B}$ antigen of $\mathrm{C} 3$. The tubes were then transferred to a $37^{\circ} \mathrm{C}$ water bath and after $5 \mathrm{~min}$ the reaction was stopped by placing the tubes back in ice and the measurements of $\mathrm{B}$ antigen and $\mathrm{Ba}$ repeated. Data for serum specimens from SLE patients that contained preformed $\mathrm{Ba}$ were not included in this study. The concentrations of the $\mathrm{C} 3 \mathrm{NeF}$ preparations were adjusted so that under the above conditions, they produced a $\mathrm{Ba}$ concentration equivalent to $3.5 \mathrm{mg}$ activated factor $\mathrm{B} / \mathrm{dl}$ when added to PNHS. The kinetics of the reaction of $\mathrm{C} 3 \mathrm{NeF}$ with PNHS and with two specimens of SLE serum were studied by measuring $\mathrm{Ba}$ after incubation with two different amounts of $\mathrm{C} 3 \mathrm{NeF}$ for varying periods.

To determine the effect of heparin on Ba formation, PNHS to which increasing amounts of heparin had been added was incubated with $\mathrm{C} 3 \mathrm{NeF}$ as above. The heparin was of porcine origin and contained 176 U. S. Pharmacopeia U/mg (Sigma Chemical Co.).

Mixing experiments to detect free inhibitor. Two target sera were used in mixing experiments. The first was the pool of NHS (PNHS) described above. The second was obtained from a healthy individual who was presumably heterozygous deficient in $\mathrm{H}(\mathrm{H}$ concentration, 3.2 SD below the mean). This serum is designated low $\mathrm{H}$ target serum. The concentrations of other components in this target serum, measured immunochemically and expressed in standard deviations from the mean, were: $\mathrm{Clq},+0.7 ; \mathrm{C} 2,-0.1 ; \mathrm{C} 4,-0.3 ; \mathrm{C} 3,-1.8$; factor $\mathrm{B},-1.5$; factor $I,-0.3$; and factor $P,-1.7$. Both target sera were stored in aliquots at $-70^{\circ} \mathrm{C}$ that were discarded after use.

In preliminary mixing experiments to detect free inhibitor, the two target sera, SLE sera and 1:1 mixtures of the two were mixed with various dilutions of the $\mathrm{C} 3 \mathrm{NeF}$ preparation with the tubes immersed in an ice bath. After removing aliquots for the measurement of $\mathrm{Ba}$, the tubes were incubated for $5 \mathrm{~min}$ at $37^{\circ} \mathrm{C}$, returned to the ice bath, and aliquots again removed for measurement of $\mathrm{Ba}$. As a result of these observations, the method used for surveying large numbers of serum specimens for free inhibitor used the low $\mathrm{H}$ target serum. $10 \mu \mathrm{l}$ of $\mathrm{C} 3 \mathrm{NeF}$ was added to $25 \mu \mathrm{l}$ of this target serum and $25 \mu \mathrm{l}$ of the test serum in a glass tube immersed in ice. Samples were taken for Ba measurement, the tubes incubated, and Ba measured again as described above.

The degree of inhibition was expressed as a ratio of the $\mathrm{Ba}$ concentration observed to that expected as determined from the $\mathrm{Ba}$ concentrations in target and test serum reacted separately with $\mathrm{C} 3 \mathrm{NeF}$. The equation was as follows: inhibition ratio $=(2[\mathrm{Ba}]$ mixture $) /[\mathrm{Ba}]$ target $+[\mathrm{Ba}]$ test.

Activation by $F\left(a b^{\prime}\right)_{2}$ anti-H. Anti-H, raised in goats, was partially purified by octanoic acid precipitation as previously described (17). 
This preparation was digested with pepsin (Sigma Chemical Co.) and the $\mathrm{F}\left(\mathrm{ab}^{\prime}\right)_{2}$ anti-H isolated from free $\mathrm{Fc}$ fragments by molecular sieve chromatography on Sephacyl S-200 (Pharmacia Fine Chemicals) (23).

To generate $\mathrm{Ba}, 20 \mu \mathrm{l}$ of the $\mathrm{F}\left(\mathrm{ab}^{\prime}\right)_{2}$ anti-H was added to $50 \mu \mathrm{l}$ of serum in the cold and the mixture incubated for $5 \mathrm{~min}$ at $37^{\circ} \mathrm{C}$. The reaction was stopped by addition of $1 \mu \mathrm{l}$ of $0.4 \mathrm{M}$ EDTA in addition to placing the tubes in ice. Samples were removed pre- and postincubation to quantitate loss of the $\mathrm{B}$ antigen of $\mathrm{C} 3$, Ba formation, and residual $\mathrm{H}$ (by RID).

To deplete serum of $\mathrm{H}$, preliminary experiments were done in which various amounts of $\mathrm{F}\left(\mathrm{ab}^{\prime}\right)_{2}$ anti-H were added to serum specimens of known $\mathrm{H}$ concentration in ice, the mixture centrifuged in the cold, and the residual $\mathrm{H}$ concentration measured by RID. From this data, a factor was determined that allowed calculation of the amount of $\mathrm{F}\left(\mathrm{ab}^{\prime}\right)_{2}$ anti-H to add to a serum of known $\mathrm{H}$ concentration to deplete it of $\mathrm{H}$. Serum so depleted, containing $<3 \mathrm{mg} / \mathrm{dl}$ of $\mathrm{H}$ (normal range: $37-69 \mathrm{mg} / \mathrm{dl}$ ), was placed in a glass tube in ice, $0.15 \mathrm{M} \mathrm{NaCl}$ or dilutions of purified $\mathrm{H}$ were then added, and the mixture split into two parts. One part was incubated at $37^{\circ} \mathrm{C}$ for $5 \mathrm{~min}$, the tube returned to ice, and 0.4 M EDTA added to stop the reaction. The second part remained in ice and EDTA was added. $\mathrm{Ba}$ and $\mathrm{H}$ levels were then measured in all mixtures.

Assessment of SLE-H function in a purified component system. Purified $\mathrm{C} 3$ was converted to $\mathrm{C} 3 \mathrm{~b}$ by incubation for $5 \mathrm{~min}$ at $37^{\circ} \mathrm{C}$ with $0.22 \%(\mathrm{wt} / \mathrm{wt}) \mathrm{N}$-tosyl-L-phenylalanine chloromethyl ketone trypsin (Sigma Chemical Co.), followed by a 5 -min incubation with $0.44 \%$ soybean trypsin inhibitor (Sigma Chemical Co.). Increments of $\mathbf{H}$ isolated from either normal plasma or SLE serum were mixed with a constant amount of either SLE or normal C $3 \mathrm{~b}$ and a constant, limiting amount of $\mathrm{I}$. After incubation at $37^{\circ} \mathrm{C}$ for $30 \mathrm{~min}$, the samples were reduced with 2-mercaptoethanol and prepared for polyacrylamide electrophoresis in the presence of SDS-PAGE as described by Laemmli (24). Slab gels (4\% acrylamide stacking, $10 \%$ separating), $0.75 \mathrm{~mm}$ thick, were used in a Protean apparatus (Bio-Rad Laboratories, Inc., Richmond, CA). Densitometry of the fixed and stained protein bands was performed on a Quick Scan densitometer with peak integration by the Quick Quant III (Helena Laboratories, Beaumont, TX).

Statistical analysis. Multiple linear regression analysis was used for correlation of $\mathrm{H}$ concentration and Ba formation. $t$ test was used for comparison of data from patients and normal subjects.

\section{Results}

Effect of C3NeF on NHS and sera from patients with SLE. The results of incubation of PNHS and serum from patients with SLE with C3NeF at two different concentrations for up to $60 \mathrm{~min}$ at $37^{\circ} \mathrm{C}$ are shown in Fig. $1 .^{2}$ In PNHS there was a rapid increase in $\mathrm{Ba}$ formation with time; using the larger amount of $\mathrm{C} 3 \mathrm{NeF}$, maximum $\mathrm{Ba}$ concentration was reached in $5 \mathrm{~min}$. With SLE sera, Ba was formed more slowly, particularly with SLE-1. With this serum, virtually no Ba was formed in $5 \mathrm{~min}$ even when large amounts of $\mathrm{C} 3 \mathrm{NeF}$ were used. In the experiments to follow, sera were incubated with an amount of $\mathrm{C} 3 \mathrm{NeF}$ intermediate between the amounts employed in these experiments and an incubation time of 5 min was used to measure the initial rate of the reaction and to maximize differences between patient and normal serum. The results of the studies to be reported would have been similar had a longer incubation time been used.

2. The C3 concentrations in the sera used for these experiments, expressed in standard deviations from the mean were as follows: PNHS, +1.62; SLE-1, -0.79 ; SLE-2, +1.62. The factor B concentrations were: PNHS, +1.1; SLE-1, -2.6 ; SLE-2, +1.93. These specimens contained $25 \mathrm{U}$ of $\mathrm{B}$ antigen per milligram of $\mathrm{C} 3$ (normal range for fresh serum 25-29) and none contained preformed Ba.

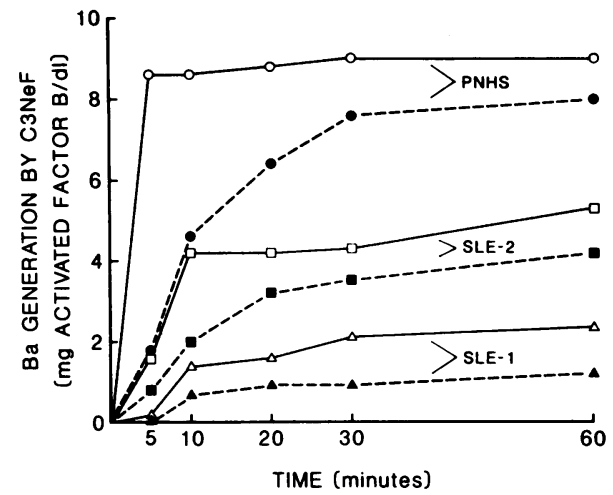

Figure 1. Kinetics of Ba formation by two different amounts of C3NeF. Ba formation plotted vs. time is shown for PNHS (circles), SLE-1 serum (triangles), and SLE-2 serum (squares). The amount of $\mathrm{C} 3 \mathrm{NeF}$ added to obtain the points represented by open symbols was twice that to obtain points represented by closed symbols.

In NHS, a direct relationship between the quantity of Ba formed and of $\mathrm{C} 3$ converted at $5 \mathrm{~min}$ was observed (Fig. 2). This relationship is compatible with the assumption that $\mathrm{Ba}$ formation measures amplification convertase $(\mathrm{C} 3 \mathrm{~b}, \mathrm{Bb})$ formation. A plateau is reached at high $\mathrm{Ba}$ concentrations because at these concentrations C3 conversion approached $100 \%$. The relationship also held in SLE sera in that C3 conversion was reduced commensurate with the inhibition in $\mathrm{Ba}$ formation. Thus, the inhibition appears to be limited to convertase formation; that convertase that is formed in SLE sera functions normally.

As can be seen in Fig. 2, in the 33 specimens of NHS incubated with $\mathrm{C} 3 \mathrm{NeF}$ under the standard conditions employed, the concentration of $\mathrm{Ba}$ varied from 1.4 to $8 \mathrm{mg}$ activated factor $\mathrm{B} / \mathrm{dl}$. To determine the basis for this variability, $\mathrm{Ba}$ generation was plotted vs. the serum concentrations of $\mathrm{H}$, a protein which combines with $\mathrm{C} 3 \mathrm{~b}$ to prevent convertase formation and which mediates decay dissociation of convertase once formed (25). It is apparent from this plot, shown in Fig. 3 , that in specimens of NHS there was an inverse relationship between the quantity of $\mathrm{Ba}$ generated and the serum $\mathrm{H}$ concentration $(r=-0.68)$. Graphs of Ba generation vs. I concentration or for $\mathrm{Ba}$ generation vs. $\mathrm{H}+\mathrm{I}$ concentrations, each expressed as percentage of normal, showed greater scatter than that for $\mathrm{Ba}$ versus $\mathrm{H}$ concentration.

$\mathrm{Ba}$ generation by $\mathrm{C} 3 \mathrm{NeF}$ in the serum of patients with SLE is also shown in Fig. 3. In nearly all cases, less Ba was formed than in NHS and in some specimens none was formed. In contrast to NHS, no relationship was discernible between the concentration of $\mathrm{H}$ in SLE sera and the quantity of Ba formed.

Ba formation was compared in serum specimens with various $\mathrm{H}$ concentrations by dividing the actual $\mathrm{Ba}$ concentration by the $\mathrm{Ba}$ concentration expected for the serum $\mathrm{H}$ concentration as determined from the regression line in Fig. 3. Values for this ratio for all 24 patients with SLE and 41 normal subjects are shown in Fig. 4. In the normal subjects, the ratio ranged from 0.6 to 1.6 . In contrast, the ratios in six patients with SLE with renal involvement studied at the onset of their disease before institution of therapy with corticosteroid were consistently $<0.6$ and usually $<0.2$. The ratio was similar in specimens obtained during treatment of active disease. 


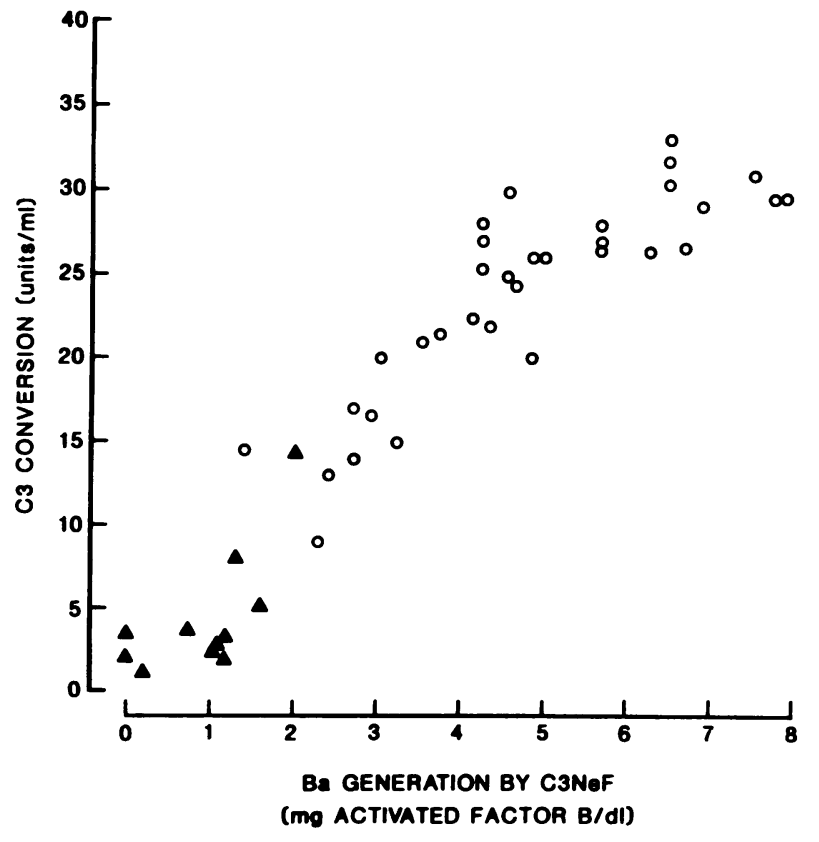

Figure 2. Relation between $\mathrm{Ba}$ generation in response to $\mathrm{C} 3 \mathrm{NeF}$, expressed as activated factor $\mathrm{B}$, and $\mathrm{C} 3$ conversion, expressed as loss of the $B$ antigen of $C 3$. The results are for specimens from 33 normal subjects and 11 patients with active SLE. $\circ$, normal subjects; $\Delta$, active disease under treatment.

During clinical remission, however, 2 of 14 patients had normal ratios $(>0.6)$, but in many the ratio was still very low. Ratios similar to those of patients in remission were found in five patients with extrarenal lupus who were not being treated with corticosteroid.

The roles of $C 3$ and factor $B$ in the inhibition of convertase formation. Because $\mathrm{C} 3 \mathrm{~b}$, the activated form of $\mathrm{C} 3$, is essential

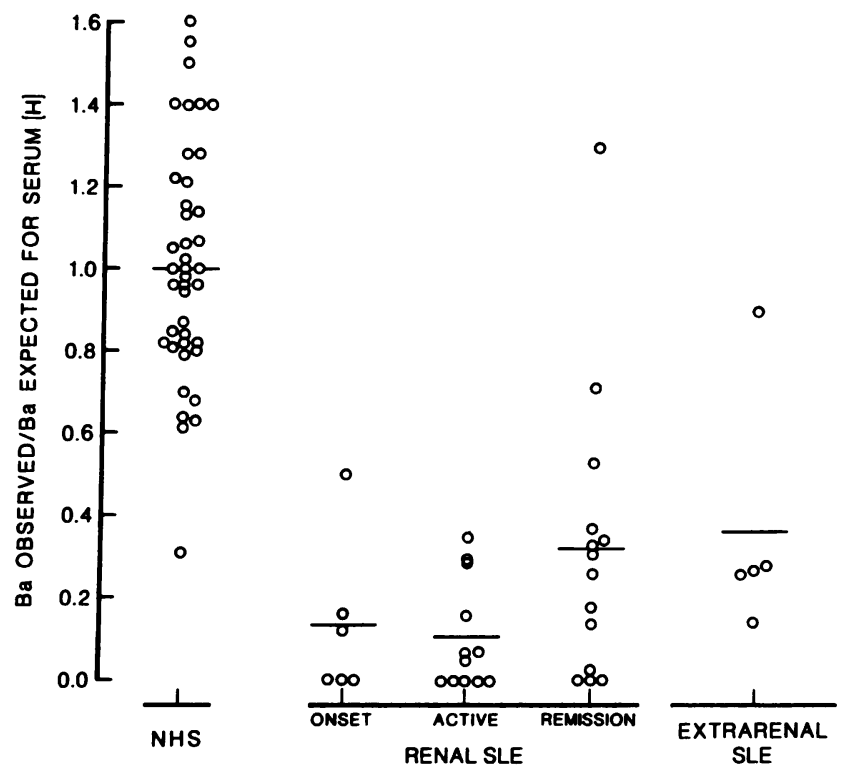

Figure 4. Ratio of $\mathrm{Ba}$ generation observed to that expected for serum factor $\mathbf{H}$ concentration in specimens from 41 normal subjects and 19 patients with renal SLE. Six specimens were obtained at onset of disease before start of therapy, 12 during treatment of active disease with corticosteroids, and 14 during remission. Data for five patients with extra-renal SLE are also shown.

for convertase formation, a reduced serum C3 concentration, often seen in patients with SLE, could be responsible for the inhibition of $\mathrm{Ba}$ formation. A plot of Ba formation vs. serum C3 concentration (Fig. 5) illustrates that this was not a factor in the serum specimens studied. Many of the specimens were obtained while the patients were normocomplementemic; inhibition of convertase formation could be complete at $\mathrm{C} 3$ levels at the upper limit of the normal range. A graph of $\mathrm{Ba}$

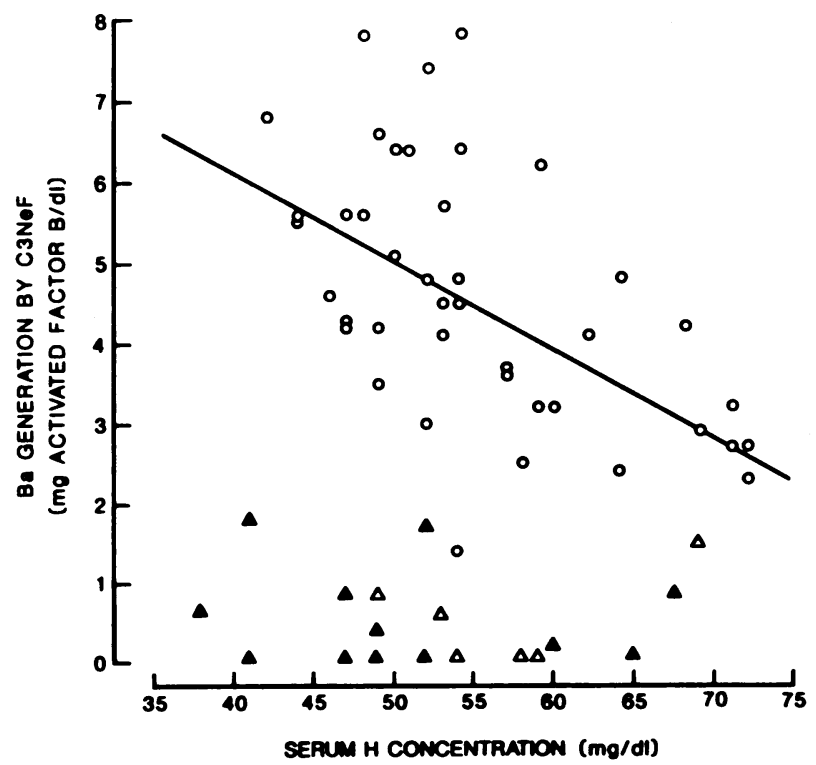

Figure 3. Relationship between the serum $\mathrm{H}$ concentration and $\mathrm{Ba}$ generation by $\mathrm{C} 3 \mathrm{NeF}$. Data for specimens from 14 normal subjects and for 18 specimens from 14 patients with SLE. O, NHS; $\triangle$, SLE at onset; $\triangle$, SLE active during therapy.

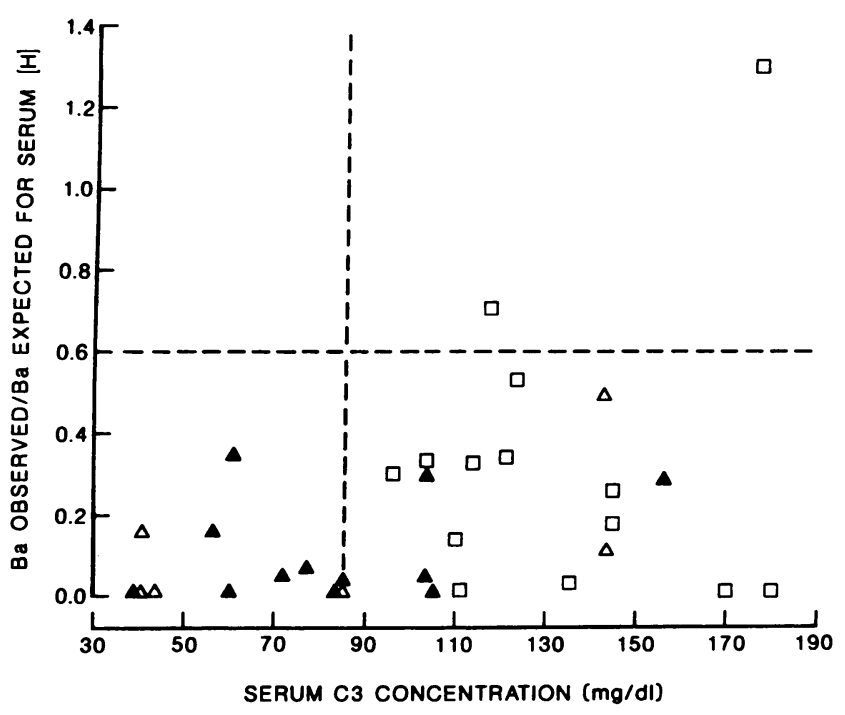

Figure 5. Ratio of Ba generation observed to that expected vs. serum C3 concentration. The normal range for the ratio is $0.6-1.5$, and for serum C3 86-169 mg/dl. Points are for 19 patients with renal SLE with specimens obtained at stages of disease as indicated in Fig. 4. $\Delta$, SLE onset; $\triangle$, SLE active; ฉ, SLE remission. 
formation vs. factor B levels (not shown) showed a similar scatter. There could be marked inhibition at low, medium, or high serum levels of factor $B$.

The effect of adding purified preparations of normal $\mathrm{C} 3$ and factor B to SLE serum is shown in Table I. The purified preparations were added at $0^{\circ} \mathrm{C}$ to PNHS or SLE serum and the mixtures incubated with $\mathrm{C} 3 \mathrm{NeF}$ for $5 \mathrm{~min}$ at $37^{\circ} \mathrm{C}$. As shown in Table I, addition of $\mathrm{C} 3$ to NHS resulted in a modest increase in $\mathrm{Ba}$ formation while the addition of factor $\mathrm{B}$ markedly augmented $\mathrm{Ba}$ formation. In contrast, the addition of C3 and factor B to the sera of patients with SLE had little effect on Ba formation. The slight increase with addition of factor B to SLE-1 serum may be within the error of the method at these low $\mathrm{Ba}$ concentrations. It is noteworthy that the C3 and factor B levels were comparable in SLE-2 serum and PNHS.

Evidence that an inhibitor of convertase formation is present in excess in SLE serum. To determine whether an inhibitor of convertase formation is present in excess in the sera of patients with SLE, mixing experiments were performed. Patient sera were mixed in equal volumes with either PNHS or low $\mathrm{H}$ target serum (see Methods). The mixtures were incubated with $\mathrm{C} 3 \mathrm{NeF}$ for $5 \mathrm{~min}$ at $37^{\circ} \mathrm{C}$ and $\mathrm{Ba}$ formation compared with that expected. There was evidence of excess inhibitor in many SLE sera when mixed with the low $\mathrm{H}$ target serum. However, when mixed with PNHS, only a few SLE sera demonstrated clear evidence of excess inhibitor.

To clarify these conflicting results, the dose response to C3NeF in mixtures containing SLE sera and either PNHS or low $\mathrm{H}$ target serum was studied. As illustrated in Fig. $6 \mathrm{~A}$, when an SLE serum forming little $\mathrm{Ba}$ with $\mathrm{C} 3 \mathrm{NeF}(\mathrm{Ba} / \mathrm{Ba}$ expected $<0.1$ ) was mixed with either PNHS or low $\mathrm{H}$ target serum, less $\mathrm{Ba}$ was produced than expected, which indicated the presence of free inhibitor, until very high doses of $\mathrm{C} 3 \mathrm{NeF}$ were used. The inhibition was again most apparent with the low $\mathrm{H}$ target serum. In contrast, as illustrated in Fig. $6 \mathrm{~B}$, when SLE serum forming more $\mathrm{Ba}$ with $\mathrm{C} 3 \mathrm{NeF}(\mathrm{Ba} / \mathrm{Ba}$ expected $>0.1$ ) was used, excess inhibitor was demonstrable only in mixtures containing the low $\mathrm{H}$ target serum. Again, at high doses of $\mathrm{C} 3 \mathrm{NeF}$, excess inhibitor was not demonstrable.

The above experiments give evidence that free inhibitor in SLE serum is most readily demonstrated when the $\mathrm{H}$ concentration of the mixture is low. With a low $\mathrm{H}$ concentration, more $\mathrm{H}$-susceptible, non-C3NeF stabilized convertase is formed. Free inhibitor in serum manifests itself in the serum mixtures by inhibiting the formation of this non-C3NeF stabilized convertase. With a normal $\mathrm{H}$ concentration in the mixture, less nonstabilized convertase is recruited, which limits the ability to detect excess inhibitor. As a corollary of this, as can be seen in Fig. 6, $A$ and $B$, high concentrations of $\mathrm{C} 3 \mathrm{NeF}$ that stabilize most, or all, of the convertase formed also prevent detection of excess inhibitor.

Because of the above observations, subsequent mixing experiments were performed using the low $\mathrm{H}$ target serum. The results, expressed as an inhibition ratio (see Methods), are shown in Fig. 7. In 16 specimens of NHS, this ratio ranged from 1.0 to 1.5. The reason this ratio averages greater than unity is not clear. Numerous specimens of SLE serum in which inhibition of convertase formation could be demonstrated were tested by this method, and many of the specimens gave inhibition ratios $<1.0$, which indicated the presence of excess inhibitor (Fig. 7). There was no significant difference between the inhibition ratios in specimens obtained at the onset of disease, during clinically active disease, or during clinical remission. Of the specimens from five patients with extrarenal SLE, free inhibitor could not be demonstrated in four.

Mixing experiments were performed longitudinally on serum specimens from five patients (Fig. 8). The amount of inhibition varied little in individual patients whether the disease was at onset, under treatment, or in remission, which indicated that when free inhibitor is demonstrable, it is present at a relatively constant level over long periods.

Relation between inhibition of $\mathrm{Ba}$ generation and the inhibition index in mixing experiments. There was only a rough correlation between the amount of Ba generated in SLE serum in response to $\mathrm{C} 3 \mathrm{NeF}$ and the amount of free inhibitor as assessed by mixing experiments. As shown in Fig. 9, excess inhibitor could be demonstrated in all of 14 serum specimens with a very low $(<0.1)$ ratio of $\mathrm{Ba}$ to $\mathrm{Ba}$ expected for the serum $\mathrm{H}$ concentration. In specimens in which the ratio of $\mathrm{Ba}$ to $\mathrm{Ba}$ expected was $>0.1$, free inhibitor could be demonstrated in only half

$F\left(a b^{\prime}\right)_{2}$ anti-H augmented amplification convertase formation. Spontaneous amplification convertase formation occurs with the addition $\mathrm{F}\left(\mathrm{ab}^{\prime}\right)_{2}$ anti-H to serum. Thus, the $\mathrm{F}\left(\mathrm{ab}^{\prime}\right)_{2}$ anti-H provides an independent means of detecting the inhibitor. Absence of the $\mathrm{Fc}$ portion of the anti-H prevents classical pathway activation by the resulting $\mathrm{H}$-anti- $\mathrm{H}$ immune complex. $\mathrm{F}\left(\mathrm{ab}^{\prime}\right)_{2}$ anti-H was added to serum specimens in an amount which in preliminary experiments was found to reduce the serum $\mathrm{H}$ concentration about two-thirds, the mixture incubated $5 \mathrm{~min}$ at $37^{\circ} \mathrm{C}$, and Ba formation compared with that produced by $\mathrm{C} 3 \mathrm{NeF}$. The data for seven specimens of NHS and 21 specimens from patients with SLE, given in Fig. 10, indicate that the inhibitor in SLE serum can be demonstrated by this means also. In both patient serum and in NHS, Ba formation

Table I. Ba Generation After 5-Min Incubation with C3NeF; Effect of Addition of Normal C3 and B to SLE Serum

\begin{tabular}{|c|c|c|c|c|c|c|c|c|c|}
\hline & \multicolumn{3}{|c|}{ Original reaction mixture } & \multicolumn{3}{|c|}{ After $\mathrm{C} 3$ addition } & \multicolumn{3}{|c|}{ After $B$ addition } \\
\hline & [C3] & [B] & [Ba] & [C3] & [B] & [Ba] & [C3] & [B] & [Ba] \\
\hline & $m g / d l$ & $m g / d l$ & $m g / d l$ & $m g / d l$ & $m g / d l$ & $m g / d l$ & $m g / d l$ & $m g / d l$ & $m g / d l$ \\
\hline SLE-1 & 71 & 20.2 & 0.2 & 104 & 18.7 & 0.4 & 59 & 34.5 & 1.3 \\
\hline SLE-2 & 117 & 27.9 & 0.9 & 147 & 25.8 & 0.3 & 97 & 42.0 & 0.7 \\
\hline PNHS & 135 & 23.3 & 3.7 & 165 & 21.5 & 4.4 & 112 & 37.5 & 9.4 \\
\hline
\end{tabular}



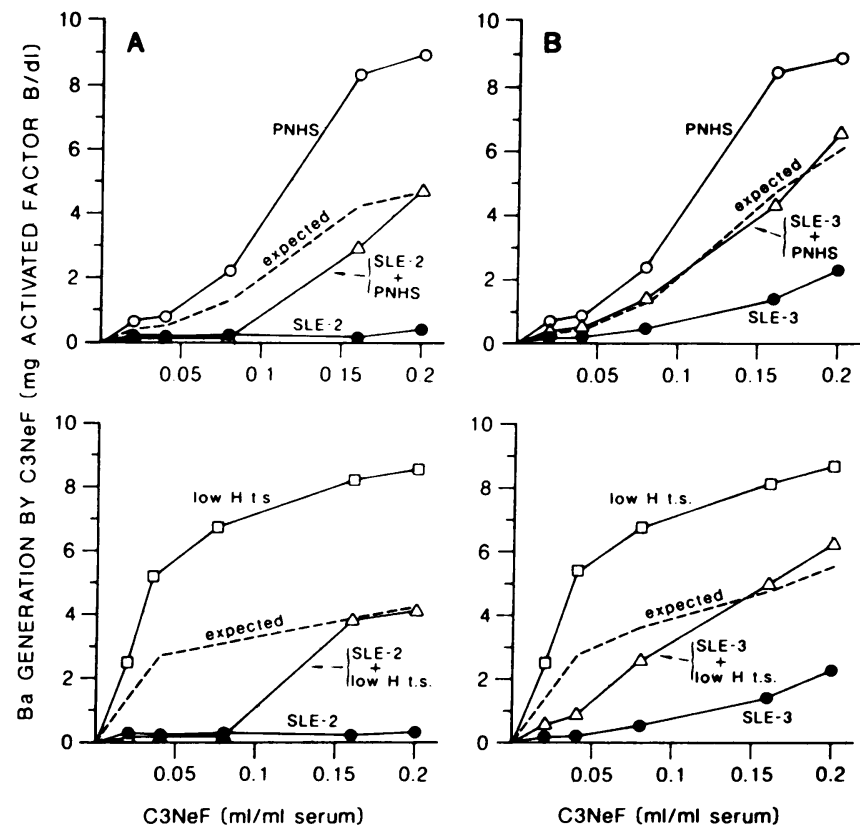

C3NeF (ml/ml serum)

Figure 6. Demonstration of excess inhibitor, dependence on $\mathrm{H}$ concentration of target serum and concentration of $\mathrm{C} 3 \mathrm{NeF}$. Ba generation by incubation with varying amounts of $\mathrm{C} 3 \mathrm{NeF}$ is shown for a PNHS, a low $\mathrm{H}$ target serum, two specimens of SLE serum, and serum mixtures. Ba generation in the SLE- 2 serum which contained large amounts of inhibitor is indicated by solid circles in $A$ and in the SLE-3 serum containing less inhibitor, which is also indicated by solid circles in $B$. Ba generation in 1:1 mixtures of these SLE sera with either PNHS or low $\mathrm{H}$ target serum is indicated by the open triangles. Ba generation expected in the mixture is indicated by the dashed line.

resulting from incubation with $\mathrm{F}\left(\mathrm{ab}^{\prime}\right)_{2}$ anti-H correlated well with that produced by $\mathrm{C} 3 \mathrm{NeF}$. At the dosages used, $\mathrm{F}\left(\mathrm{ab}^{\prime}\right)_{2}$ anti-H formed more Ba than did $\mathrm{C} 3 \mathrm{NeF}$.

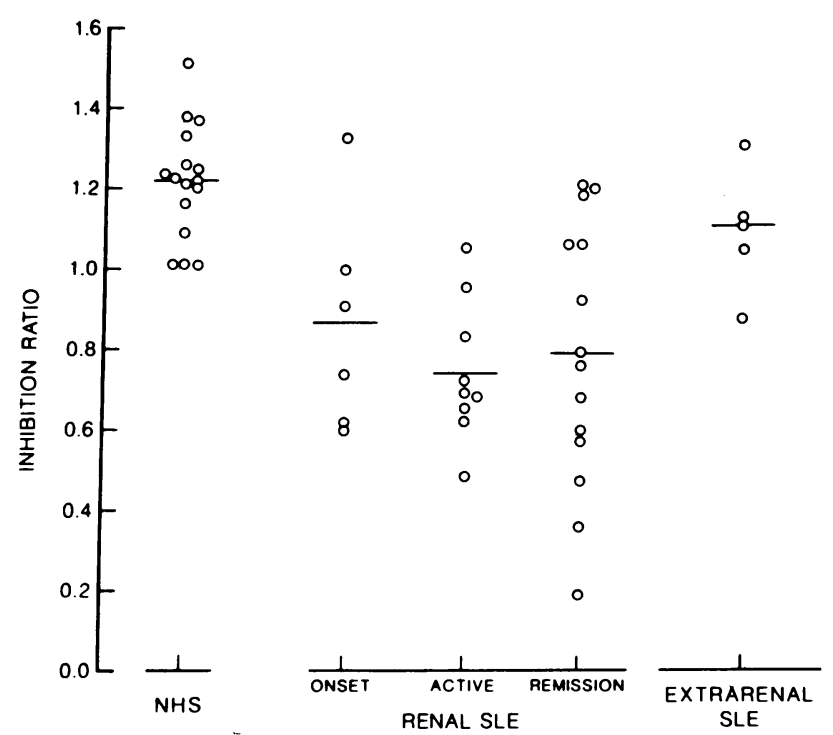

Figure 7. Inhibition ratio determined from mixing experiments using specimens from 16 normal subjects and 19 patients with renal SLE. Six specimens were obtained at onset, nine during active disease and fourteen during remission. Five were from patients with extra-renal SLE. A ratio $<1.0$ indicates presence of excess inhibitor in the serum.

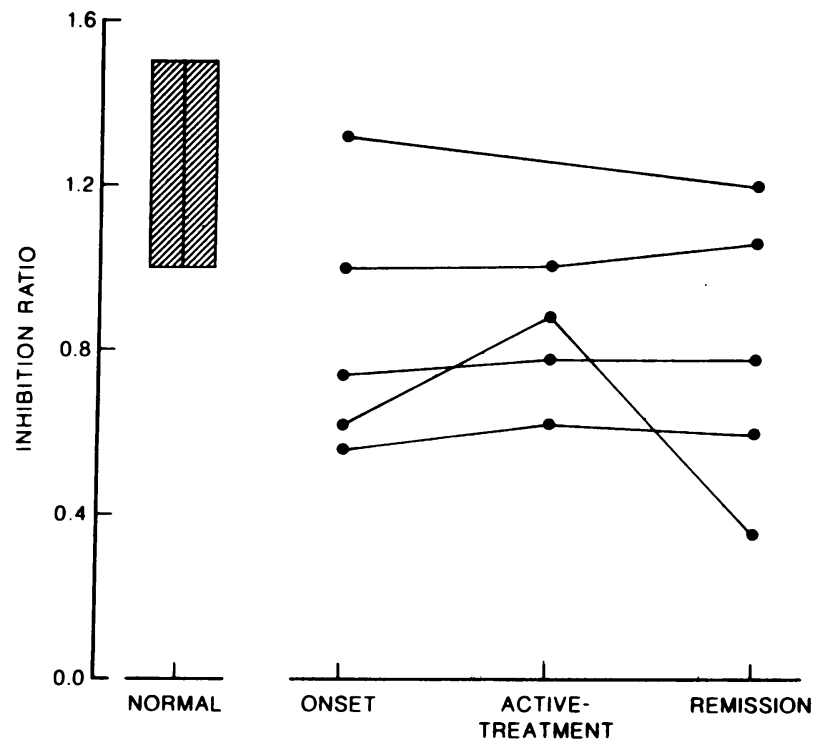

Figure 8. Inhibition ratios determined serially in five patients with renal SLE. The range for normal sera is indicated by the vertical bar.

Dependence of the inhibitor on factor $H$. In the course of experiments employing the $\mathrm{F}\left(\mathrm{ab}^{\prime}\right)_{2}$ anti-H, it was found that the inhibitor is not demonstrable in the absence of $\mathrm{H}$. Experiments demonstrating this are shown in Fig. 11. To PNHS and serum from patients with SLE was added a sufficient quantity of $F\left(a b^{\prime}\right)_{2}$ anti-H to remove virtually all the $H$, which produced a serum designated RH. To aliquots of these preparations, incremental amounts of purified normal $\mathrm{H}$ were added. The mixtures were then incubated for $5 \mathrm{~min}$ at $37^{\circ} \mathrm{C}$, returned to ice, and EDTA added to stop the reaction.

As shown in Fig. 11, Ba formation, expressed as percentage

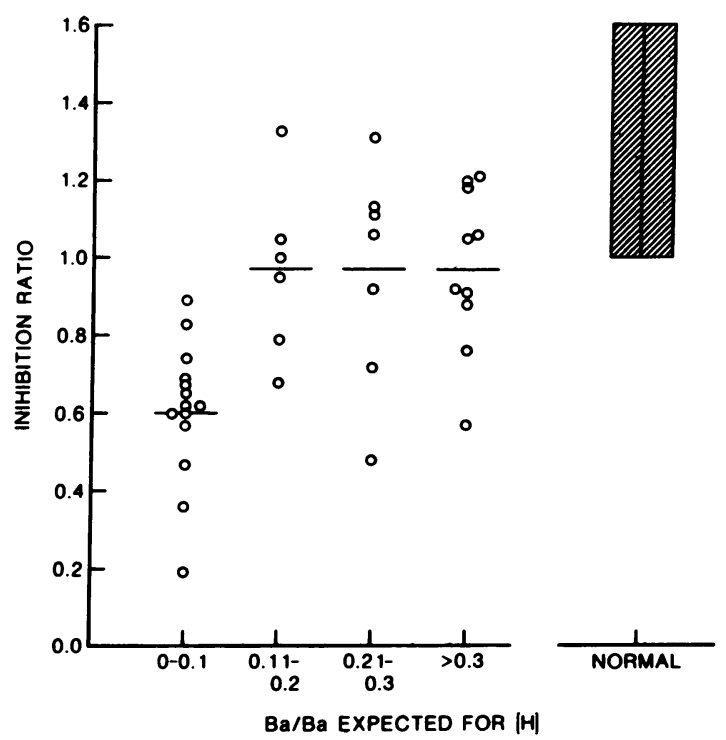

Figure 9. Inhibition ratios determined from mixing experiments using serum specimens that demonstrated varying degrees of inhibition of convertase formation. Inhibition of convertase formation is expressed by the ratio of $\mathrm{Ba}$ observed to that expected for the serum $\mathrm{H}$ concentration. The range for normal sera is indicated by the vertical bar. 


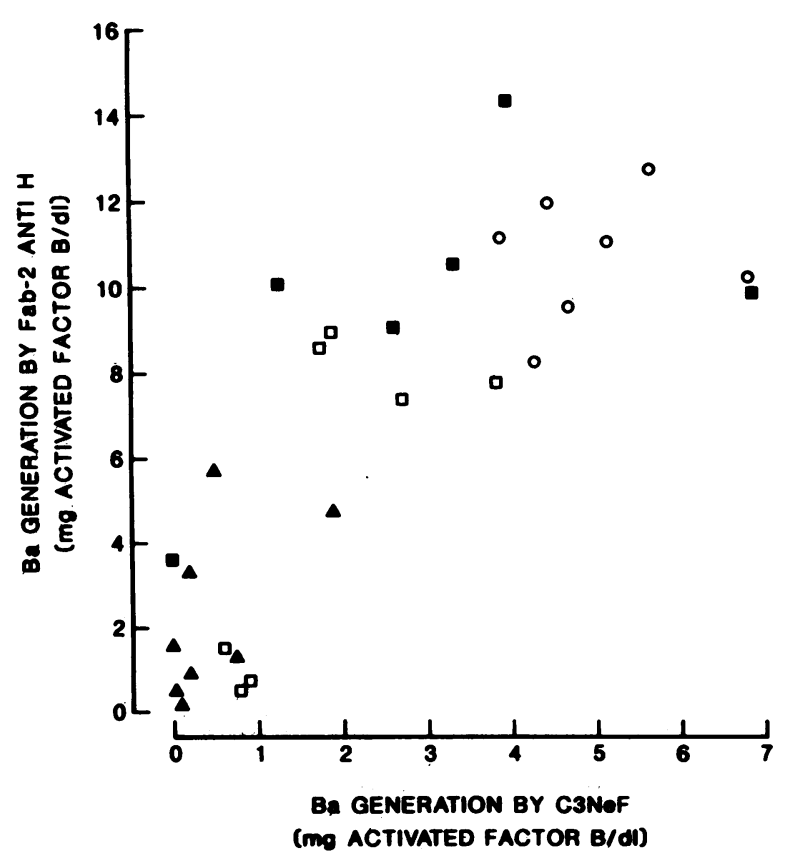

Figure 10. Spontaneous $\mathrm{Ba}$ formation by inactivation of $\mathrm{H}$ with $F\left(a b^{\prime}\right)_{2}$ anti $H$ vs. Ba generation by C3NeF. O, NHS; $\triangle$, SLE active; $\square$, SLE remission; $n$, SLE extrarenal.

of factor $\mathrm{B}$, was, in the absence of $\mathrm{H}$, virtually the same in all serum specimens even though the SLE sera used contained large amounts of inhibitor. When normal $\mathrm{H}$ was added back to the SLE RH, inhibition of convertase formation was again demonstrable; $\mathrm{H}$ was far more effective in inhibiting $\mathrm{Ba}$ formation in SLE serum than in PNHS. The results indicate that the inhibitor greatly increases the sensitivity of $\mathrm{C} 3 \mathrm{~b}$ to inactivation by $\mathrm{H}$, but that removing the $\mathrm{H}$ from SLE serum and replacing it with normal $\mathrm{H}$ does not correct the inhibition. This suggests that the $\mathrm{H}$ in SLE serum is not abnormal per se

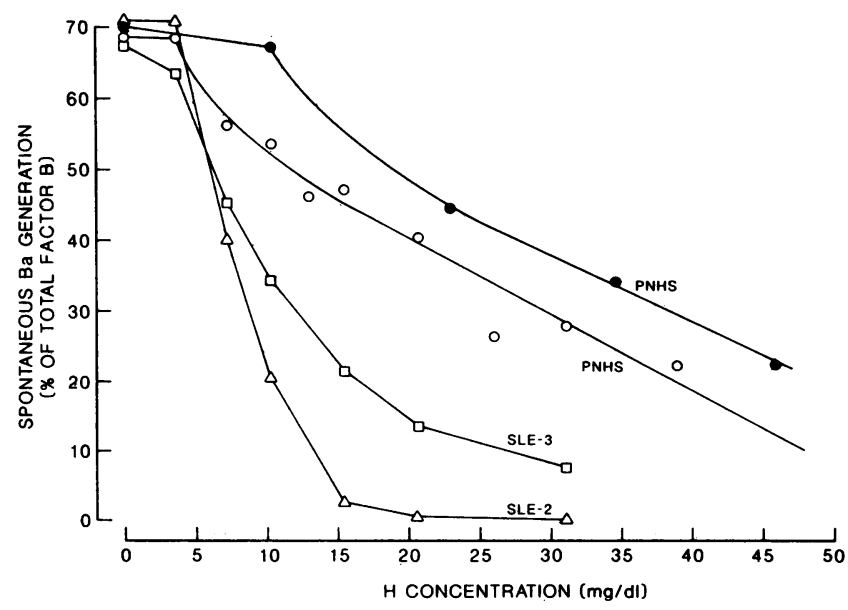

Figure 11. Effect of incremental additions of normal $\mathrm{H}$ and $\mathrm{H}$ isolated from SLE serum to several RH preparations. Spontaneous $\mathrm{Ba}$ generation is plotted vs. $\mathrm{H}$ concentration in the reaction mixture. Results of incremental addition of normal $\mathrm{H}$ to two SLE sera depleted of $\mathrm{H}$ and to PNHS depleted of $\mathrm{H}$ are indicated by the open symbols. Results of addition of $H$ isolated from SLE serum to the RH made from PNHS are indicated by the solid circles. and that any $\mathrm{H}$ in that milieu would be more effective. To confirm this, $\mathrm{H}$ was isolated from SLE serum and added incrementally to an RH made from PNHS. As shown in Fig. 11 , the relationship of $\mathrm{Ba}$ formation to $\mathrm{H}$ concentration closely resembled that seen when normal $\mathrm{H}$ is added to PNHS. The $\mathrm{H}$ obtained from SLE serum was, if anything, slightly less effective than normal $\mathbf{H}$ in preventing Ba formation. Only an $\mathrm{H}$ that was much more effective than normal would explain the inhibition seen in SLE serum.

In a further effort to detect a component abnormality in SLE serum, the ability of $\mathrm{H}$ and $\mathrm{C} 3 \mathrm{~b}$ from a patient with SLE to interact with normal $\mathrm{C} 3 \mathrm{~b}$ and $\mathrm{H}$ was monitored in mixtures of purified components. After SDS-PAGE, reduced C3b produces two protein bands representing the alpha' and beta chains. As $\mathrm{C} 3 \mathrm{~b}$ is degraded to $\mathrm{iC} 3 \mathrm{~b}$ by $\mathrm{H}$ and $\mathrm{I}$, the alpha' chain is cleaved into two smaller fragments (26). Thus the dose-response of a constant amount of $\mathrm{C} 3 \mathrm{~b}$ to increments of $\mathrm{H}$ can be measured by the decrease in density of the alpha' chain band relative to the constant density of the beta chain. Densitometric measurement of the protein bands after SDSPAGE of the incubated mixtures show that $\mathrm{H}$ derived from SLE serum was no more effective than the $\mathrm{H}$ derived from PNHS in cleaving the alpha' chain of C3b (Fig. 12). In the same way, it was demonstrated that $\mathrm{C} 3 \mathrm{~b}$ derived from SLE serum was not more susceptible to cleavage by $\mathrm{H}$ and $\mathrm{I}$ than its normal counterpart (data not shown). Neither the C3 nor the $\mathrm{H}$ preparations showed evidence of proteolysis and both were free of contaminating proteins.

Simulation of inhibitor effect by heparin. Heparin, added

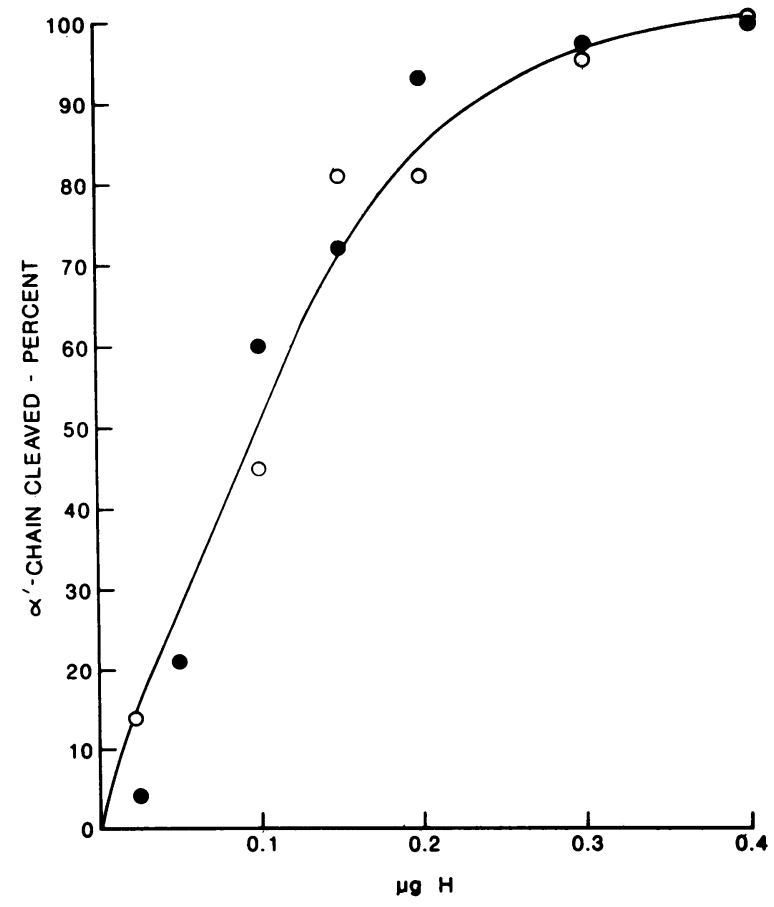

Figure 12. Percent cleavage of the $\alpha^{\prime}$-chain of normal C3b in mixtures of $\mathrm{H}$ and $\mathrm{I}$. The closed circles denote cleavage by increasing amounts of normal $\mathrm{H}$ plus constant amounts of normal $\mathrm{I}$, and the open circles denote cleavage by increasing amounts of $\mathrm{H}$ derived from SLE serum plus constant amounts of normal I. All mixtures contained $2 \mu \mathrm{g} \mathrm{C} 3$ and $0.1 \mu \mathrm{g}$ I and were adjusted to a constant volume with PBS. 
to serum, has recently been shown to bind to $\mathrm{H}$ and potentiate the ability of $\mathrm{H}$ to inactivate $\mathrm{C} 3 \mathrm{~b}(27)$. It was demonstrated further in the study that, as in SLE serum, inhibition of convertase formation by heparin was not demonstrable in the absence of $\mathrm{H}$ and the inhibitory effect of heparin could be restored by addition of purified $\mathrm{H}$ to the mixture. The ability of heparin to prevent convertase formation was confirmed in the present study; Ba formation in response to incubation of NHS with $\mathrm{C} 3 \mathrm{NeF}$ was inhibited slightly at a heparin concentration of $20-30 \mu \mathrm{g} / \mathrm{ml}$ and markedly inhibited at a concentration of $100 \mu \mathrm{g} / \mathrm{ml}$ (Fig. 13). As would be expected, activation of $\mathrm{C} 3$ was depressed commensurate with the depression of $\mathrm{Ba}$ formation.

It was shown previously (27) that addition of heparin to serum increased the electrophoretic mobility of $\mathrm{H}$. This was also observed in this laboratory. However, electrophoretic analysis of SLE serum containing excess inhibitor showed $\mathrm{H}$ to have the same mobility as the $\mathrm{H}$ in NHS.

Attempts to further identify the inhibiting factor. Because of the diversity of autoantibodies observed in patients with SLE, the possibility that an immunoglobulin was increasing the sensitivity of $\mathrm{C} 3 \mathrm{~b}$ to $\mathrm{H}$ was investigated. The IgG fractions of NHS and SLE-4 serum with high inhibitor content were isolated by ion exchange chromatography. Incremental amounts of the isolated IgG were mixed with NHS, C3NeF added, and the mixture incubated at $37^{\circ} \mathrm{C}$ for $5 \mathrm{~min}$. As shown in Fig. 14 , there was no evidence of inhibition of convertase formation by IgG from either source.

Sera from several patients with SLE were extensively dialyzed at $4^{\circ} \mathrm{C}$ against veronal-buffered saline with physiologic concentrations of $\mathrm{Ca}++$ and $\mathrm{Mg}++$ using dialysis tubing with a molecular cutoff of 12,000-14,000 mol wt. No loss of inhibitory activity occurred, which suggested that the molecular weight of the inhibitor was $>14,000$.

\section{Discussion}

Immune complex deposition and the resultant inflammatory response are important in the pathogenesis of SLE. Deposition of $\mathrm{C} 3 \mathrm{~b}$ on immune complexes, occurring mainly by recruitment of the alternative pathway, causes solubilization and opsonization and may thus be an important means of preventing

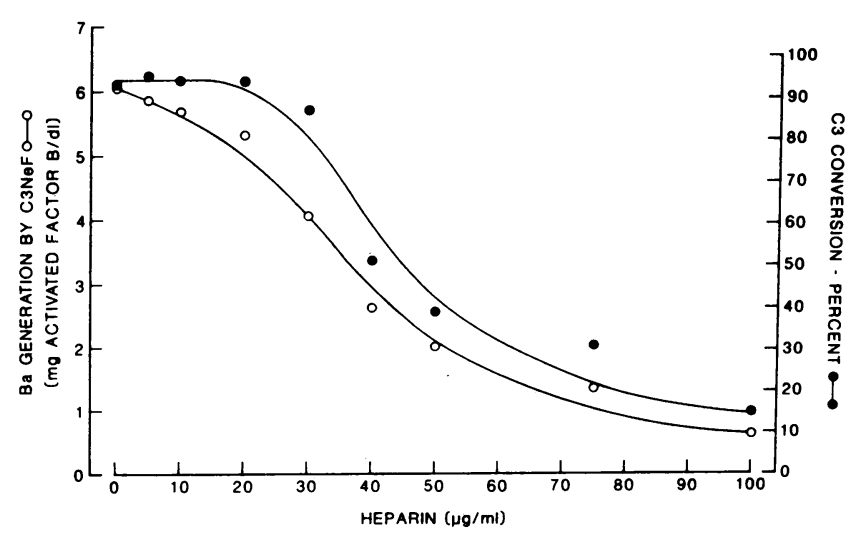

Figure 13. Inhibition by heparin of convertase (Ba) formation and C3 conversion in NHS. After addition of incremental amounts of heparin to NHS, C3NeF was added as in previous experiments and $\mathrm{Ba}$ generation and $\mathrm{B}$ antigen loss was measured after a 5-min incubation at $37^{\circ} \mathrm{C}$.

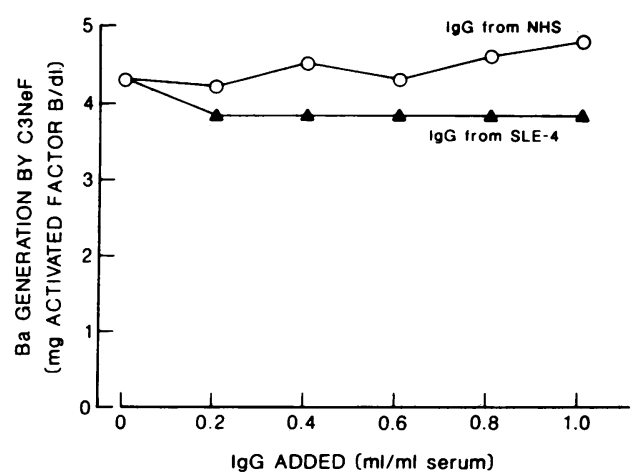

Figure 14. Effect of IgG from SLE serum on Ba generation. Increasing amounts of IgG isolated from NHS and SLE-4 serum were added to NHS, the volumes of the mixtures equalized by adding $0.15 \mathrm{M}$ $\mathrm{NaCl}$, and the amplification loop activated by incubating the $\mathrm{C} 3 \mathrm{NeF}$.

tissue deposition $(1,2)$. We have studied fluid-phase amplification $\mathrm{C} 3$ convertase $(\mathrm{C} 3 \mathrm{~b}, \mathrm{Bb})$ formation in sera from patients with SLE using a new assay and found it to be markedly diminished. In this assay, $\mathrm{C} 3 \mathrm{NeF}$, an autoantibody to $\mathrm{C} 3 \mathrm{~b}, \mathrm{Bb}$, was used to promote amplification loop turnover. $\mathrm{C} 3 \mathrm{NeF}$ added to a serum sample stabilizes nascent $\mathrm{C} 3 \mathrm{~b}, \mathrm{Bb}$, making it resistant to decay dissociation by $\mathrm{H}$, and the resultant unregulated $\mathrm{C} 3 \mathrm{~b}$ formation initiates loop turnover. In normal serum, extensive $\mathrm{C} 3$ conversion and $\mathrm{C} 3 \mathrm{~b}, \mathrm{Bb}$ formation, as measured by formation of the factor $\mathrm{B}$ fragment, $\mathrm{Ba}$, occurs. The initial rate of this reaction is measured by a 5 -min incubation at $37^{\circ} \mathrm{C}$ (Fig. 1). There was a linear relationship between the quantity of $\mathrm{Ba}$ formed and the extent of $\mathrm{C} 3$ conversion (Fig. 2 ), which indicated that $\mathrm{Ba}$ formation reflects effective convertase formation. It was observed that the quantity of convertase formed in NHS was, to some extent, inversely related to the $\mathrm{H}$ concentration (Fig. 3 ). This reflects the fact that $\mathrm{H}$ combines with $\mathrm{C} 3 \mathrm{~b}$ to prevent effective convertase formation and in addition mediates decay dissociation of that recruited convertase not stabilized by $\mathrm{C} 3 \mathrm{NeF}$. The relationship thus gives evidence that in NHS, under the reaction conditions used, $\mathrm{C} 3 \mathrm{~b}, \mathrm{Bb}$ was recruited in excess of the available $\mathrm{C} 3 \mathrm{NeF}$. Thus, $\mathrm{C} 3 \mathrm{~b}, \mathrm{Bb}$ not stabilized by $\mathrm{C} 3 \mathrm{NeF}$ was formed. In contrast, convertase formation in sera from patients with SLE was markedly diminished and had no demonstrable relation to serum $\mathbf{H}$ concentration within the physiologic range (Fig. 3).

SLE and normal sera with various $H$ concentrations were compared by correcting convertase formation for serum $\mathrm{H}$ concentration (Fig. 4). The inhibition of convertase formation was demonstrable at all levels of disease activity and in the presence or absence of therapy. Inhibition of convertase formation was not related to a deficiency of any complement component measured. In particular, C3 and factor B were present in normal concentrations in the sera of a majority of the patients (Fig. 5), including some with severe inhibition. Furthermore, addition of purified normal factor B or C3 to SLE sera did not restore convertase formation (Table I).

Mixing experiments not only gave evidence that in some sera, an inhibitor of convertase formation was present in excess (Fig. 7), but also shed light on the nature of the inhibition. Comparison of the results of experiments employing variable quantities of $\mathrm{C} 3 \mathrm{NeF}$ and using PNHS and a serum with a low $\mathrm{H}$ concentration as target sera (Fig. $6, A$ and $B$ ) indicated that the inhibition was only demonstrable under conditions in 
which the convertase generated is not stabilized by $\mathrm{C} 3 \mathrm{NeF}$. Free inhibitor was, therefore, most readily demonstrated in mixtures with a low $\mathrm{H}$ concentration to which relatively small amounts of $\mathrm{C} 3 \mathrm{NeF}$ were added. The mixing experiments also ruled out low concentrations of classical pathway components or a possible deficiency of factor D in SLE serum as the cause of the inhibition, since these components would be supplied by the target serum. The amount of excess inhibitor was found to vary from patient to patient, but that present remained relatively constant regardless of the clinical state (Fig. 8). Sera producing little $\mathrm{Ba}$ with $\mathrm{C} 3 \mathrm{NeF}$ addition were most frequently found to have excess inhibitor in mixing experiments (Fig. 9).

In additional studies, spontaneous convertase formation in response to partial depletion of factor $\mathrm{H}$ from serum by addition of $F\left(a b^{\prime}\right)_{2}$ anti-H was found to be inhibited in SLE serum to the same extent as convertase formation produced by $\mathrm{C} 3 \mathrm{NeF}$ (Fig. 10). However, in SLE serum from which $\mathrm{H}$ had been totally or subtotally removed, inhibition of convertase formation could not be demonstrated (Fig. 11). The requirement that $\mathrm{H}$ be present to demonstrate inhibition indicates that the inhibition is mediated through $\mathrm{H}$ and, therefore, the result of increased sensitivity of $\mathrm{C} 3 \mathrm{~b}$ to inactivation by $\mathrm{H}$.

The possibility that an abnormal $\mathrm{H}$ with an increased affinity for C3b was present in SLE serum was explored in three ways. First, SLE serum was depleted of $\mathrm{H}$ and normal $\mathrm{H}$ added back. If an abnormal $\mathrm{H}$ had been present in SLE serum, Ba generation at various levels of added normal $\mathbf{H}$ would have been the same as in PNHS. However, inhibition of convertase formation was still demonstrable (Fig. 11). Since Ba generation was markedly inhibited by the addition of very small amounts of normal $\mathbf{H}$ to the $\mathbf{H}$-depleted SLE serum, it appears that some factor in that serum potentiated the interaction of $\mathrm{C} 3 \mathrm{~b}$ and $\mathrm{H}$. Secondly, $\mathrm{H}$ isolated from a specimen of SLE serum was added to an RH made from PNHS. The relationship between $\mathrm{H}$ concentration and spontaneous $\mathrm{Ba}$ generation was essentially the same as when normal $\mathrm{H}$ was added to an RH of PNHS (Fig. 11). Third, SDS-PAGE of mixtures of purified $\mathrm{C} 3 \mathrm{~b}, \mathrm{H}$, and I demonstrated no abnormality in the functional interaction of SLE-derived $\mathrm{H}$ with $\mathrm{C} 3 \mathrm{~b}$ or SLE-derived C3b with $\mathrm{H}$ (12).

In summary, the inhibition is not due to an intrinsic abnormality in $\mathrm{C} 3$ or $\mathrm{H}$. It appears to be due to an entity that can potentiate the interaction of $\mathrm{C} 3 \mathrm{~b}$ with $\mathrm{H}$ but does not copurify with either. In support of this hypothetical mechanism, soluble heparin has recently been shown to potentiate the ability of $\mathbf{H}$ to inactivate $\mathrm{C} 3 \mathrm{~b}$ (27). However, unlike heparin, the inhibitor in SLE serum appears to interact more loosely with $\mathrm{H}$ and does not change its electrophoretic or chromatographic properties. It was shown that the inhibitor was not IgG and that it had a molecular weight in excess of 12,000 14,000 .

The increased sensitivity of fluid-phase $\mathrm{C} 3 \mathrm{~b}$ to $\mathrm{H}$, observed in the present study, is reminiscent of the changes in $\mathrm{H}$ sensitivity of membrane-bound $\mathrm{C} 3 \mathrm{~b}$ in the presence of certain membrane constituents. It is well known that membraneassociated sialic acid greatly increases the $\mathrm{H}$ sensitivity of $\mathrm{C} 3 \mathrm{~b}$ bound to that surface $(28,29)$. Others have shown that $\mathrm{H}$ sensitivity also increases linearly with the number of molecules of heparin bound to zymozan particles (30). C-reactive protein (CRP) appears to have the same effect; C3b deposited on Streptococcus pneumoniae that has been reacted with CRP will bind twice as much $\mathrm{H}$ as that bound to $S$. pneumoniae not reacted with CRP (31). It is not clear how these surface molecules alter the sensitivity of $\mathrm{C} 3 \mathrm{~b}$ to $\mathrm{H}$. To date, no naturally occurring substance has been described which in the fluid phase will increase the sensitivity of $\mathrm{C} 3 \mathrm{~b}$ to $\mathrm{H}$ as observed in the present study.

Studies by others (32-36) employing the sera of patients with immune complex disease suggest that the inhibitor of fluid-phase convertase formation described here would reduce the ability of serum to solubilize complexes. These studies have measured the ability of serum to either solubilize preformed immune complexes $(4,33)$ or to prevent precipitation of complexes formed by antigen and antibody added separately to serum (34). Normal serum both solubilizes preformed complexes and inhibits precipitation of de novo complexes. Solubilization requires an intact alternative pathway but is more rapid and complete if the classical pathway is intact also (7). Inhibition of precipitation requires that both the classical and alternative pathway be intact (34). Both depend on the deposition of $\mathrm{C} 3 \mathrm{~b}$ on the lattice. Two groups $(32,33)$ have shown that preformed complexes are poorly solubilized by SLE sera and Naama et al. (35) showed that immune complexes formed in SLE sera precipitated rather than remaining in solution. The same was true of sera from patients with seropositive rheumatoid arthritis, which indicated that the abnormality in SLE was not necessarily the result of hypocomplementemia. The authors then demonstrated (36) that complexes formed in 1:1 mixtures of NHS and sera from patients with rheumatoid arthritis precipitated, which suggested a circulating inhibitor of solubilization present in excess. The inhibitor was more frequently and readily demonstrable when serum specimens from patients were heated to $56^{\circ} \mathrm{C}$ for 30 min. It was shown to be a protein but was not further characterized.

Alternative pathway activity, measured by hemolysis of rabbit red blood cells, has been found to be inhibited in the sera of patients with SLE (37). The inhibition correlated well with serum $\mathrm{C} 3$ and $\mathrm{C} 4$ levels, leading the authors to conclude that consumption of components through triggering of the C3b amplification loop by the in vivo classical pathway activation had decreased the activity of the alternative pathway. This explanation appears to be correct, since the correlations they observed would not be predicted if an inhibitor such as described in the present paper were responsible for the alternative pathway inhibition. An inhibitor that increases the sensitivity of fluid-phase $\mathrm{C} 3 \mathrm{~b}$ or fluid-phase $\mathrm{C} 3 \mathrm{~b}, \mathrm{~B}$ to $\mathrm{H}$ would not demonstrably affect $\mathrm{C} 3 \mathrm{~b}$ or $\mathrm{C} 3 \mathrm{~b}, \mathrm{~B}$ present on an alternative pathway activator, such as rabbit red cells. Much further study will be necessary to identify the inhibitor and determine whether it is the same as, or similar to, the inhibitor of immune complex solubilization in SLE and rheumatoid arthritis described by others $(32,33,36)$ and whether it has a role in the pathogenesis of immune complex disease.

\section{Acknowledgments}

We thank Ms. Barbara Cody of the Children's Hospital Research Foundation Electrophoresis Laboratory for graciously performing the densitometry.

This work was partially supported by grants AM 28315, AM 26279, and AM 33636 and by Institutional National Research Service Award AM 07051 to Dr. Waldo, all from the National Institutes of Health. 


\section{References}

1. Takahashi, M., J. Czop, A. Ferreiro, and V. Nussenzweig. 1976. Mechanism of the solubilization of immune aggregates by complement. Implications for immunopathology. Transplant. Rev. 32:121-139.

2. Takahashi, M., S. Takahashi, and S. Hirose. 1980. Solubilization of antigen-antibody complexes: a new function of complement as a regulator of immune reactions. Prog. Allergy. 27:134-166.

3. Czop, J., and V. Nussenzweig. 1976. Studies on the mechanism of solubilization of immune precipitates by serum. J. Exp. Med. 143: 615-630.

4. Miller, G. W., and V. Nussenzweig. 1975. A new complement function: solubilization of antigen-antibody aggregates. Proc. Natl. Acad. Sci. USA. 72:418-422.

5. Van Swick, J. L., and P. L. Masson. 1978. The effect of complement on the ingestion of soluble antigen-antibody complexes and IgM aggregates by mouse peritoneal macrophages. J. Exp. Med. 148:903-914.

6. Kijlstra, A., L. A. vanEs, and M. R. Daha. 1979. The role of complement in the binding and degradation of immunoglobulin aggregates by macrophages. J. Immunol. 123:2488-2493.

7. Takahashi, M., S. Takahashi, V. Brade, and V. Nussenzweig. 1978. Requirements for the solubilization of immune aggregates by complement: the role of the classical pathway. J. Clin. Invest. 62:349358.

8. Fujita, T., Y. Takata, and N. Tamura. 1981. Solubilization of immune precipitates by six isolated alternative pathway proteins. J. Exp. Med. 154:1743-1751.

9. Medof, M. E., G. M. Prince, and C. Mold. 1982. Release of soluble immune complexes from immune adherence receptors on human erythrocytes is mediated by $\mathrm{C} 3 \mathrm{~b}$ inactivator independently of beta $1 \mathrm{H}$ and is accompanied by generation of $\mathrm{C} 3 \mathrm{c}$. Proc. Natl. Acad. Sci. USA. 79:5047-5051.

10. Rynes, R. I. 1982. Inherited complement deficiency states and SLE. Clin. Rheum. Dis. 8:29-47.

11. Vogt, W., L. Dieminger, R. Lynen, and G. Schmidt. 1971. Alternative pathway for the activation of complement in human serum: formation and composition of the complex with cobra venom factor that cleaves the third component of complement. Hoppe-Seyler's Z. Physiol. Chem. 355:171-183.

12. Lesavre, P. H., T. E. Hugli, A. F. Esser, and H. J. MullerEberhard. 1979. The alternative pathway C3/C5 convertase: chemical basis of factor B activation. J. Immunol. 123:529-534.

13. West, C. D., N. C. Davis, J. Forristal, J. Herbst, and R. E. Spitzer. 1966. Antigenic determinants of human beta $1 \mathrm{C}$ and beta $1 \mathrm{~A}$ globulins. J. Immunol. 96:650-658.

14. Ruley, E. J., J. Forristal, N. C. Davis, C. Andres, and C. D. West. 1973. Hypocomplementemia of membranoproliferative nephritis: dependence of the nephritic factor reaction on properdin factor B. J. Clin. Invest. 52:896-904.

15. Wyatt, R. J., A. J. McAdams, J. Forristal, J. Snyder, and C. D. West. 1979. Glomerular deposition of complement-control proteins in acute and chronic glomerulonephritis. Kidney Int. 16:505512.

16. Strife, C. F., B. M. McDonald, E. J. Ruley, A. J. McAdams, and C. D. West. 1976. Shunt nephritis: the nature of the serum cryoglobulins and their relation to the complement profile. J. Pediatr. 88:403-413.

17. Steinbuch, M., and R. Audran. 1969. The isolation of IgG from mammalian sera with the aid of caproic acid. Arch. Biochem. Biophys. 134:279-284.

18. Hammer, C. H., G. H. Wirtz, L. Renfer, H. D. Gresham, and B. F. Tack. 1980. Large scale isolation of functionally active components of the human complement system. J. Biol. Chem. 256:3995-4006.

19. Lambris, J. D., N. J. Dobson, and G. D. Ross. 1980. Release of endogenous $\mathrm{C} 3 \mathrm{~b}$ inactivator from lymphocytes in response to triggering membrane receptors for beta $1 \mathrm{H}$ globulin. J. Exp. Med. 152: 1625-1644.
20. Gardner, W. D.; P. J. White, and S. L. Hoch. 1980. Identification of a major serum DNA-binding protein as beta $1 \mathrm{H}$ of the alternative pathway of complement activation. Biochem. Biophys. Res. Commun. 94:61-67.

21. Ngam, B. Y., and J. O. Minta. 1981. Proteolysis of C2 and factor B: analyses of cleavage products by one- and two-dimensional peptide mapping. Mol. Immunol. 18:1035-1047.

22. Boenisch, T., and C. A. Alper. 1970. Isolation and properties of a glycine rich beta glycoprotein of human serum. Biochim. Biophys. Acta. 221:529-535.

23. Garvey, J. S., N. E. Cremer, and D. H. Sussdorf. 1977. Methods in Immunology. The Benjamin/Cummings Publishing Co., Reading, MA. Third ed. 256-266.

24. Laemmli, U. K. 1970. Cleavage of structural proteins during the assembly of the head of bacteriophage T4. Nature (Lond.). 227: 680-685.

25. Whaley, K., and S. Ruddy. 1976. Modulation of the alternative complement pathway by beta $1 \mathrm{H}$ globulin. J. Exp. Med. 144:11471163.

26. Pangburn, M. K., R. D. Schreiber, and H. J. Muller-Eberhard. 1977. Human complement C3b inactivator: isolation, characterization and demonstration of an absolute requirement for the serum protein beta $1 \mathrm{H}$ for cleavage of $\mathrm{C} 3 \mathrm{~b}$ and $\mathrm{C} 4 \mathrm{~b}$ in solution. J. Exp. Med. 146: 257-270.

27. Boackle, R. J., G. B. Caughman, J. Vesely, G. Medgyesi, and H. Fudenberg. 1983. Potentiation of factor $H$ by heparin: a ratelimiting mechanism for inhibition of the alternative complement pathway Mol. Immunol. 20:1157-1164.

28. Fearon, D. T. 1978. Regulation by membrane sialic acid of beta $1 \mathrm{H}$ dependent decay-dissocation of amplification $\mathrm{C} 3$ convertase of the alternative complement pathway. Proc. Natl. Acad. Sci. USA. 75:1971-1975.

29. Pangburn, M. K., and H. J. Muller-Eberhard. 1978. Complement $\mathrm{C} 3$ convertase: cell surface restriction of beta $1 \mathrm{H}$ control and generation of restriction on neuraminidase-treated cells. Proc. Natl. Acad. Sci. USA. 75:2416-2420.

30. Kazatchkine, M. D., D. T. Fearon, J. E. Silbert, and K. F. Austen. 1979. Surface-associated heparin inhibits zymozan-induced activation of the human alternative complement pathway by augmenting the regulatory action of the control proteins on particle-bound C3b. J. Exp. Med. 150:1202-1215.

31. Mold, C., M. Kingzette, and H. Gewurz. 1984. C-reactive protein inhibits pneumococcal activation of the alternative pathway by increasing the interaction between factor $\mathrm{H}$ and $\mathrm{C} 3 \mathrm{~b}$. J. Immunol. 133:882-885.

32. Aguado, M. T., L. H. Perrin, P. A. Miescher, and P. H. Lambert. 1981. Decreased capacity to solubilize immune complexes in serum from patients with systemic lupus erythematosus. Arthritis Rheum. 24:1225-1229.

33. Schifferli, J. A., S. M. Morris, A. Dash, and D. K. Peters. 1981. Complement-mediated solubilization in patients with systemic lupus erythematosus, nephritis or vasculitis. Clin. Exp. Immunol. 46:557564.

34. Schifferli, J. A., S. R. Bartolotti, and D. K. Peters. 1980. Inhibition of immune precipitation by complement. Clin. Exp. Immunol. 42:387-394.

35. Naama, J. K., W. S. Mitchell, A. Zoma, J. Veitch, and K. Whaley. 1983. Complement mediated inhibition of immune precipitation in patients with immune complex diseases. Clin. Exp. Immunol. 52:292-298.

36. Naama, J. K., W. S. Mitchell, and K. Whaley. 1983. Inhibition of complement mediated solubilization of antigen-antibody complexes by sera from patients with rheumatoid arthritis. Clin. Exp. Immunol. 54:429-438.

37. Aguado, M. T., L. H. Perrin, R. Ramirez, P. A. Miescher, and P. H. Lambert. 1980. Evaluation of alternative pathway and factor B hemolytic activity in patients with systemic lupus erythematosus: correlations with the alternative pathway regulatory proteins. Clin. Exp. Immunol. 42:495-505. 